INTERNATIONAL JOURNAL OF RESEARCHES IN BIOSCIENCES, AGRICULTURE AND TECHNOLOGY (C) VISHWASHANTI MULTIPURPOSE SOCIETY (Global Peace Multipurpose Society) R. No. MH-659/13(N) www.vmsindia.org

\title{
FOSSIL SPORES RAMANUJAMOSPORITES MOHGAOENSE GEN. NOV. SP. NOV. FROM MOHGAONKALAN INTERTRAPPEAN BEDS OF INDIA
}

\author{
S .G. Lanjewar ${ }^{1}$, S. D. Puranik ${ }^{2}$, R. S. Sakundarwar ${ }^{2}$ and P. D. Burghate² \\ ${ }^{1}$ Eco Agri seeds, Hyderabad.-500082,India. \\ 2,Shivaji Science College, Nagpur. \\ sumedhadpuranik@gmail.com
}

\begin{abstract}
:
Present paper deals with fungal spores Ramanujamosporites mohgaoense gen. Nov. Sp. Nov. Spore 3celled,uniseriate,inaperturate,elongated,dark melanin coloured, septa prominent, broken at places, spore wall irregular, basal cell processed. The present spore different from all described fossil spp. And so it is kept as seprate from genus named as Ramanujamosporites mohgaoense gen. Nov. Sp. Nov. The generic name is after Prof. Ramanujam , an eminent palaeobotanist of India, and specific name is after the locality.
\end{abstract}

Keywords : Fungal spore, uniseriate, melanin, septa.

\section{Introduction:}

The fossil fungi imperfecti from the Deccan intertrappean beds of Mohgaonkalan. Mahabale (1969) has recorded Diplodia rodei. Four different fossil pycnidia namely Palaephoma intertrappea, Mohgaonidium deccani, Mohgaonidi deccani, Diplodia sahnii and Deccanodia eocenum have been reported by Singhai (1974). Above pycnidia are from the Deccan Intertrappean beds of Mohgaonkalan in M.P. Singh and Patil (1978) reported the pycnidia Palaeocylosphaera intertrappea, Rabenharstinidium intertrappeum, Hendersonula mohgaoense, Sarcophoma deccani belonging to Coelomycetes. Barlinge and Paradkar (1979) reported the Deuteromycetous pycnidia Botryodiplodia mohgaoensis and Ascochytiles intertrappea from the same beds of Mohgaonkalan. Dixit (1984) has reported same type of fructifications from the same beds. Chawhan (1987) described three different fungal pycnidia of fungi imperfecti from Nagpur. They are Palaeosclerotipsis intertrappea, Phutalites deccani and Astermellites deccani. Here a pychidium showing affinities to form order Sphaeropsidales of fungi imperfecti is described.

\section{Material and Method:}

These spores were observed on the peel which shows presence of a fossil fruit of follicle type.These fungal spores were found engulfed in the organic matter in association with the fruit.

Description:

The present fungal spore is a 3-celled structure. It is uniseriate, inaperturate, elongated in shape and dark melanin in colour.It means $76 * 47 \mathrm{um}$ in size. The wall is irregular. The transverse septa among the three uniseriate cells of the spores are prominent and 6 um thick. These septa are broken at places. The median and basal cells have a process each emerging from the lateral and right side respectively. The terminal cells measures $26 * 39$ um, the middle is $24 * 44 \mathrm{um}$ and the basal is $22 * 36$ um in diameter.(plate-1) Figure. $-1 \& 2$

\section{Discussion:}

Many multicellate fungal spores have been described from different localities, under the name Multicellaeosporites (Elsik), 1971, Pleuricellasporites Elsik,1977,Fusiformisporites (rouse) Elsik,1968. and many other spore types are not yet assigned to any particular genus. , Puranik,S., Lanjewar \& Sakundarwar,2011, Ustilago chitaleyi.

The present spore is different from all, the above fossil sp, and so it is kept as separate from genus and named as Ramanujamosporites mohgaoense gen. nov. Sp. nov. The generic name is after Prof. Ramanujam , an eminent palaeobotanist of India, and specific name is after the locality.

\section{Diagnosis:}

\section{Generic diagnosis}

Ramanujamosporites gen. nov.

Spore 3-celled, uniseriate, inaperturate, elaongated dark melanin coloured, septa prominent, broken at places.

\section{Specific diagnosis}

R.mohgaoense sp.Nov.

Spore wall irregular, basal cells processed,76*47 um in diameter, septa 6 um thick.

Locality -Mohagaonkalan, M.P.India.

Horizon - Deccan Intertrappean series of India.

Age-Uppermost cretaceous.

Ramanuiamosporites gen. et.sp nov

Explanation of plate I, Figure.s 1 and 2

1 : The fungal spores showing 3 linear cells with a terminal and a lateral processeach. ${ }^{*} 3202$ :The fungal spores showing irregular spore wall and the broken septa. ${ }^{*} 650$

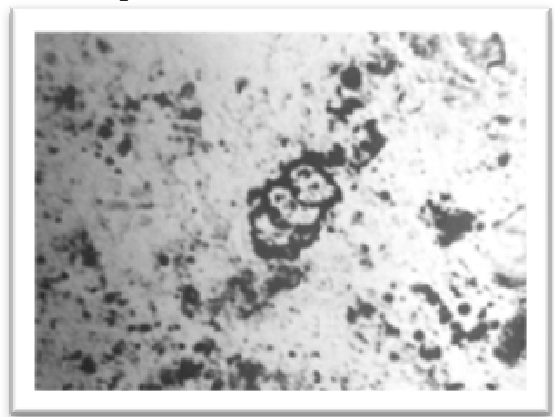

Figure. - 1 


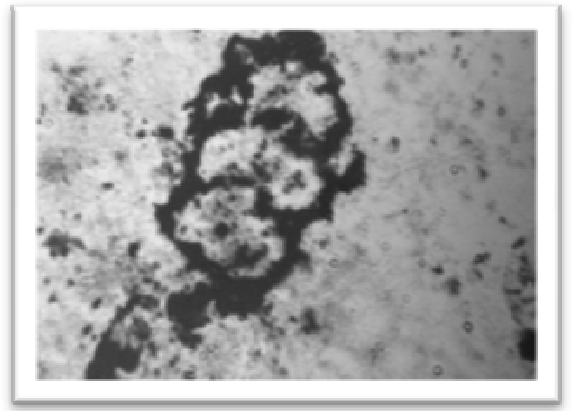

Figure. - 2

\section{References:}

Alexopoulos, C. J. 1962. Introductory mycology. Wiltey Eastern pvt.ltd.New Delhi.

Elsik W.C 1968. Palynology of a paleocene rockdale lignite, Milan Country,Texas1.Morphology and Taxanomy. J .Pollen spores.Vol.10: $263-314$.

Elsik W.C 1971. Microscopic fungal remains and cenozoic palynostratigraphy. Geoscience and man 15. 115 - 120.

Elsik W.C 1977. Morphologic phylogeny of dispersed fossil fungal spores - Intimations. Second int.Mycol.cong.univ. SouthFlorida,Tampa Abs.169.

Elsik W.C 1978. Classification and geologc history of microthyracious fungi.IV Int. Palynol. Conf. Luknow 1:331-334.

Puranik, S., Lanjewar \& Sakundarwar, 2011. A smut fungus Ustilago chitaleyi sp. nov. from the Mohagaonkalan intertrappean beds of India,vol Hislopia journal 4(2) 2011.pg no 107110.

Mahabale T. S. On a fossil species of Diplodia from the Deccan Intertrappean series, M.P.,India.Palaeobotanist, 1969; 17(3) :295-297. Singhai LC. Fossil fungi from the Deccan Intertrappean beds of M.P.,India, J.Biol . Sci., 1974; $17: 92-102$

Singh R. B. and Patil G. V. On remains of Coelomycetes in Mohgaonkalan Intertrappean M.P., India. The Botanique, 1978; 9 : 13-20.

Barlinge S. G. and Paradkar S. A. Record of new fossil algal and fungal, forms from the Deccan Intertrappean beds of Mohgaonkalan, M.P., India. The Botanique. 1979; X : 1-4.

Dixit V. P. Palaeobotanical studies of the Deccan Intertrappean. Ph.D. Thesis, Nagpur University, Nagpur, 1984.

Chawhan N. J. Contribution towards Palaeocene flora from the Intertrappean Series of India Ph.D. Thesis, Nagpur University, Nagpur, 1987. 